\title{
1 Allegories of Logos and Eros
}

Before we take up the central concern of this book - the Boethian and Joban mediation of the classical epic tradition in the Middle Ages and Renaissance-we need to recall some of the literary contexts in which Boethius wrote his sixthcentury De consolatione philosophiae. As we have seen, Bernard Silvestris considered Boethius' work to be an imitation of both Virgil's Aeneid and Martianus Capella's De nuptiis Philologiae et Mercurii, and thus the expression of a continuous Homeric tradition. All three works, he says, deal figuratively with the same thing. ${ }^{1}$ This chapter examines the historical basis for that critical judgment.

The bizarre combination in De nuptiis of weighty textbook material on the seven liberal arts with a fanciful, allegorical love story seems, to be sure, far removed from both Virgil's Aeneid and Boethius' Consolation. It does, however, call attention to two clearly marked lines of allegorical development in antiquity. As we shall see, both Boethius and Martianus, albeit in strikingly different ways, join these two lines. The first, emphasizing logos and the intellectual discovery of the causes of things, proceeds from Homer through Virgil, Macrobius, and Fulgentius. The second, emphasizing eros and the moral application of truth, also finds its origins in Homer, but proceeds through popular romance, both Greek and Roman.

1. Quoted by Winthrop Wetherbee, Platonism and Poetry in the Twelfth Century (Princeton: Princeton University Press, 1972), p. 124. 


\section{Virgil and the Allegory of Logos}

The Vitae Vergilianae and Virgil's own remarks in Georgics $2.475-82$ indicate that Virgil wanted to imitate Lucretius in writing a philosophical poem, a poem unveiling the causes of things. ${ }^{2}$ Despite Lucretius' opening invocation of Venus as "Aeneadum genetrix," the Aeneid is seldom read as Virgil's response to De rerum natura. ${ }^{3}$ Although there are clear differences in form and content between the two, Lucretius' poem offers a suggestive model for Virgil's own philosophical rewriting of Homer. As we have already seen, Lucretius draws a strong parallel between Homer and Epicurus (De rerum natura 3.1037-44). Elsewhere Lucretius summarizes the action of the Iliad to show that historical events result accidentally from body and void ("eventa . . . corporis atque loci") as first causes:

denique materies si rerum nulla fuisset
nec locus ac spatium, res in quo quaeque geruntur,
numquam Tyndaridis forma conflatus amore
ignis, Alexandri Phrygio sub pectore gliscens,
clara accendisset saevi certamina belli,
nec clam durateus Troianis Pergama partu
inflammasset equos nocturno Graiugenarum.

(De rerum natura $1.471-77$, emphasis added)

[Again, if there had been no material for things, and no place and space in which each thing is done, no fire fanned to flame by love through the beauty of Tyndareus' daughter, and glowing beneath the breast of Phrygian Alexander, would ever have set alight blazing battles of savage war; no wooden horse, unmarked by the sons of Troy, would ever have set Pergama in flames by its night-born brood of Grecians.] (pp. 40-41, emphasis added)

2. See Michael Murrin, The Allegorical Epic: Essays in Its Rise and Decline (Chicago: University of Chicago Press, 1980), pp. 11-13.

3. I quote from Lucretius, De rerum natura, trans. W. H. D. Rouse, rev. Martin F. Smith, 2nd ed., Loeb Classical Library (Cambridge: Harvard University Press, 1 975, repr. 1982). Philip R. Hardie advances the "perhaps disconcerting" thesis that $D e$ rerum natura is "a central model" for the Aeneid in Virgil's "Aeneid": Cosmos and Imperium (Oxford: Clarendon, 1986), p. 157. Murrin suggestively anticipates this approach in The Allegorical Epic. 
The imagery of the passage, which links in a causal chain the fire of love with the flames of war and the eventual burning of Troy, offers a prologue to the long philosophical discussion that follows, in which Lucretius refutes Heraclitus, Empedocles, and the Stoics, all of whom consider fire, not solid matter, to be the original substance of things: "primordia rerum / mollia" (1.753-54). ${ }^{+}$Lucretius, in short, first envisions a Stoic reading of Homer, a reading that posits fire as the elemental beginning and end of the Trojan war, and then argues on behalf of the atomists for solid matter as antecedent to fire.

Lucretius' imagined Stoic reading derives from Stoic allegoresis of the Iliad. As Cicero's Balbus bears witness, Stoic theory deified the air lying between the sea and the sky, naming it Hera (later, Juno) because of its close connection with aether, the cosmic fire associated with Zeus (later, Jove), Hera's brother and husband. ${ }^{5}$ The Stoics thus discovered behind Homer's imagistic pantheon a true natural philosophy according to which, for instance, Hera's cloud-covered copulation with Zeus on Mt. Ida (Il. 14.153-355; 15.1-84) encoded an elemental description of a springtime thunderstorm-air (Hera) coupling with fire (Zeus). ${ }^{6}$ Lucretius, however, goes beyond such sporadic exegesis, which served to explain problematic passages individually, in isolation from the Iliad as a whole, and gives to fire (and thus to Jove) ultimate causality for the whole action of Homer's epic, unifying it from beginning to end.

The Stoic reading of Homer that Lucretius first posits and then rejects bears striking resemblance to Virgil's own reading and rewriting of Homer. It is virtually a critical commonplace to recognize Stoic elements informing the Aeneid. The epic's proem, which makes a wrathful Juno responsible for Aeneas' sufferings, introduces a specifically Stoic concern ("secundum Stoicos dicit") for, as Servius notes, the Epicureans pictured the gods as disinterested in human affairs: "nam Epicurei dicunt deos humana penitus non curare" (In

4. Hardie treats this passage briefly as a Lucretian precedent for the Virgilian literary device whereby "initially figurative" events become narrative actualities. See Cosmos and Imperium, pp. 232-33.

5. Cicero, De natura deorum, trans. H. Rackham, Loeb Classical Library (Cambridge: Harvard University Press, 1933, 1979), II.xxvi.66, pp. 186-87. See also Macrobius, Commentary on the Dream of Scipio, trans. William Harris Stahl (New York: Columbia University Press, 1952), I.xvii.1 2-15, pp. 157-58.

6. See Murrin, Allegorical Epic, pp. 4-7, 15. 
Vergilii Aeneidos I. 1 1). ${ }^{7}$ Aeneas' piety ("pius Aeneas") marks him as a Stoic hero, rendering his filial duty to his father and the gods; his paternal due to those entrusted to his care. ${ }^{8}$ Aeneas' heroic action and suffering result from his free acceptance of his appointed destiny, and the combination of human virtue and divine affliction in his labores make the epic as a whole a Stoic exploration of the problem of evil in a providentially ordered universe. As Servius phrases the question: "If Aeneas is just, why does he suffer under the hatred of the gods?" (In Aen. I.1 o: "si iustus est Aeneas, cur odio deorum laborat?").

Whereas Virgil's Juno is the agent of disorder, personified opposition to destiny, and the source of storms and madness, Virgil's Jupiter is, as Hainsworth phrases it, "an allegory of his historical determinism" who speaks "as if he were the mouthpiece of Fate."9 "Jupiter's will," Servius writes, "is Fate" (In Aen. IV.6 14: "fata' dicta, id est Iovis voluntas"). When Jupiter, in answer to Venus' fears, declares Fate immovable (Aen. 1.257-58: "manent immota tuorum / fata"), he expresses the Stoic teaching ("dogma Stoicorum ostendit") that Fate cannot be altered (In Aen. I.257: "nulla ratione posse fata mutari"). ${ }^{10}$ Elsewhere Servius treats the word "fata" as a past participle indicating what the gods have decreed: " 'fata' modo participium est, hoc est, 'quae dii loquuntur'" (In Aen. II.54)—words that the gods themselves must obey once they have been spoken. As Jupiter tells Venus: "necque me sententia vertit" (Aen. 1.26o). ${ }^{11}$

Virgil couples this explicit treatment of Jupiter's will as the fixed, necessary cause of things with imagery appropriate to Stoic cosmology. Jupiter makes his first appearance "aethere summo" (Aen.

7. Quotations from Servius are all taken from Servii Grammatici qui feruntur in Virgilii Carmina commentarii, ed. Georg Thilo and Hermann Hagen (Leipzig, $188_{1-}$ $87), 3$ vols. Translations of Servius are mine.

8. For an excellent study of Stoic ethics, see Brad Inwood, Ethics and Human Action in Early Stoicism (Oxford: Clarendon Press, 1985).

9. J. B. Hainsworth, The Idea of Epic (Berkeley: University of California Press, $1991)$, p. 106.

1 o. All quotations from Virgil are taken from The Aeneid of Virgil, 2 vols., ed. R. D. Williams (Basingstoke and London: Macmillan, 1972).

1 1. For studies of the antique understanding of fate, see Vincent Cioffari, Fortune and Fate from Democritus to St. Thomas Aquinas (New York: Columbia University Press, 1935); Jerold C. Frakes, The Fate of Fortune in the Early Middle Ages: The Boethian Tradition (Leiden and New York: E. J. Brill, 1988). 
1.223), in the upper, fiery air. The passage recalls the Stoic deification of aether as Jove, the primal, creative Fire that is the material origin of everything. According to this view, aether is both the world and its god ("mundus deus"), the animate force governing the mutation of its elements (air, water, earth). ${ }^{12}$ Virgil's Anchises enunciates this Stoic dogma when he associates fiery energy and a heavenly origin with the seeds of things: "igneus est ollis vigor et caelestis origo / seminibus" (Aen. 6.73o-31). Twice Virgil calls Jupiter "hominum sator atque deorum" (Aen. 1.254, 11.725 ), the sower ("sator") of gods and men, thus linking his paternity to the seeds of fire ("seminibus"), the warmth from the sky ("caldor e caelo") that is, according to Zeno, the seed of animate creatures: "animalium semen ignis is qui anima ac mens." 13

Virgil's strong association of Jupiter with both fate and fire allows him to rewrite Homer from the unified Stoic perspective Lucretius first suggested when he posited divine fire as the first and last cause of the Trojan war (De rerum natura 1.47 1-77). When Aeneas tells of his escape from burning Troy, he dwells upon his solitary encounter with Helen (Aen. 2.567-87) ${ }^{14}$ Filled with vengeful fire (2.575: "exarsere ignes animo"), he almost kills her as the cause of Troy's destruction (2.581: "Troia arserit igni"), but Venus herself intervenes to exculpate both Helen and Paris and blame instead the cruelty of the gods: "divum inclementia, divum" (2.602). Aeneas will learn this lesson over and over again as his own divine and fiery destiny casts him repeatedly, in relation to both Dido and Lavinia, in the role of another Paris.

When Aeneas speaks of the fall of Troy, Venus has already conspired with Cupid to girdle Dido with the flame of love (1.673: "cingere flamma") and kindle fire in her very bones: "incendat reginam atque ossibus implicet ignem" (1.66o). Ignorant of fate (1.299: "fati nescia"), Dido receives as a gift from Aeneas the dress and veil of

12. See Cicero, De natura deorum II.xlvi. 1 1 8, pp. 234-35; III.xvi.4o, pp. 322-23.

13. See Varro, De lingua latina, vol. 1, trans. Roland G. Kent, Loeb Classical Library (Cambridge: Harvard University Press, 1938, 1977), V.59, pp. 54-57.

14. This passage (lines $567-88$ ), supposedly suppressed and deleted by Varius and Tucca, early editors of the Aeneid, survives only in Servius' commentary. The general scholarly consensus is that the much disputed passage is authentic and provides a startling insight into Virgil's concept of the character of Aeneas. (See the commentary of R. G. Austin, Aeneidos liber secundus [Oxford: Clarendon Press, 1964], pp. 21 7-29.) 
Helen (1.65o). When she finds herself responding to Aeneas as she had to her husband Sychaeus - "agnosco veteris vestigia flammae" (4.23) - she begs Jupiter to prevent her dishonor by using lightning to send her to the underworld: "pater omnipotens adigat me fulmine ad umbras" (4.25). That prayer gains an ironic answer when Jupiter's own lightning flash during the storm occasions her pseudo-marriage to Aeneas in the cave: "fulsere ignes et conscius aether / conubiis" (4.167-68). Servius calls attention to lightning as Jupiter's characteristic sign (In Aen. I.42, I.230) and, citing Varro, interprets the celestial fire ("fulsere ignes") coupled with rain as a divine nuptial observance. ${ }^{15}$

Iarbas, however, protests that Jupiter's avenging thunderbolts (4.209: "in nubibus ignes") should not overlook Dido's scandalous affair with Aeneas. Dido's vow never to remarry, to remain faithful to her dead husband, makes her, in relation to Aeneas, another Helen; Aeneas, another Paris (4.215: "ille Paris cum semivio comitatu"). As once in Troy, the flames of love lead to battle and funeral fires as Dido, abandoned by Aeneas at Jupiter's command, kills herself upon a pyre, after cursing the Dardanians and prophesying that one of her race will pursue them with firebrand and sword: "face ... ferroque" (4.626). The departing Trojans see the walls of Carthage, like the walls of Troy, aflame: "moenia respiciens, quae iam infelicis Elissae / conlucent flammas" $(5 \cdot 3-4) .{ }^{16}$

Virgil's language makes his protagonists the followers of the gods, drawn irresistibly into a preordained course. All their actions are fated, sequenced in a causal chain. Aeneas does not freely strive to gain Italy: "Italiam non sponte sequor" (4.361, emphasis added). The dead Dido follows Aeneas and haunts him with blackened firebrands: "Sequar atris ignibus absens" (4.384). The Carthaginian Hannibal will pursue with fire the descendants of Troy: "qui face Dardanios ferroque sequare colonos" (4.626).

15. See Varro, De lingua latina V.61-62, pp. 58-59. See also J. W. Jones, Jr., “Allegorical Interpretation in Servius," Classical Journal 56 (1960-61): $217-26$, and Hardie's comments on storms and fulmen in Lucretius and Virgil, pp. $176-93$. Seneca discusses lightning from a Stoic perspective as a sign of Jupiter and fate in Naturales quaestiones II.33-50, vol. 1, trans. Thomas H. Corcoran, Loeb Classical Library (Cambridge: Harvard University Press, 1971 ), pp. 154-81.

16. Hardie lists various studies of the linked imagery of amatory and actual wounds and fire in Book 4 (Cosmos and Imperium, n. 183, p. 232). 
Even when Juno or Venus seem to initiate an action, Virgil's fiery imagery makes them agents of Jupiter and the larger, providential plan. In Book 5, for instance, the Trojan women, weary of their journey and infuriated by Juno, set the ships ablaze. Just before that turbulent scene takes place, however, Jupiter intervenes in the funeral games with a strange omen when the arrow shaft of Acestes catches fire in flight: "volans liquidis in nubibus arsit harundo / signavitque viam flammas" (5.525-26). That Jovian fire, which singles Acestes out for glory, anticipates the women's furious assault on the ships and the founding of a new Trojan city under Acestes' rule. In the end, Jupiter's own thunderbolts initiate a rainstorm to save the remnant of the fleet.

Another fiery omen underscores Jupiter's determination of the course of events in Book 7 when the sacrificial fire seems to catch in Lavinia's long hair (7.73: "visa (nefas) longis comprendere crinibus ignem") and set aflame her jewelled crown. A portent of war (7.80: "magnum portendere bellum"), it signals yet another repetition of Iliadic action. The Sibyl foretold that a foreign bride would again bring destruction to the Trojans (6.93-94) and that they would find another Achilles in Latium (6.89). Turnus' wrathful strength in battle makes him another Achilles (9.742), but his prior engagement to Lavinia likens him to Menelaus, his wife stolen, as Helen had been, by an Aeneas playing the part of another Paris (7.321: "Paris alter"). Amorous fire turns imagistically once more into the fire of war when the blush on Lavinia's burning cheek (1 2.65-69) awakens Turnus' love and increases his ardor for battle: "ardet in arma magis" ( 12.71 ). The capital city in flames-like the Stoic conflagration of an old world-moves Turnus at last to accept the will of the gods and embrace his own death at the hands of a wrathful Aeneas. The burning city thus recalls the burning of Troy and the epic ends as it began, with the tears of things (1.462: "lacrimae rerum") answering to primal fire.

Whereas Virgil, answering Lucretius, reads and rewrites Homer from a Stoic perspective, Virgil's readers come to interpret him, in turn, from a Neoplatonist point of view. As Michael Murrin observes, Virgil's polyvalent mode of divine representation, which associates Jupiter with both fate and fire, Juno with both rebellion and rain, "encouraged an allegorical reading of the whole epic" as a continu- 
ous allegory. ${ }^{17}$ Virgil's depiction of Stoic logos in the will of Jupiter thus extended itself into interpretations of Virgil's words as instances of deliberate verbal allegory concealing natural secrets of all kinds. We find in Servius' fourth-century commentary and in Macrobius' Saturnalia (c. A.D. 40o) the early flowerings of that impulse, but Fulgentius' De continentia Vergiliana (sixth century) stands as the first reading of the Aeneid as a systematic exposition of the life of Everyman.

The work of Fulgentius bears comic witness to what must have been common pedagogical practice at the time: the use of Virgil's writings as a pretext for discussing "the innermost profundities [interna viscera] of almost every art," veiled references to which grammarians found in the line-by-line analysis of his poems. ${ }^{18}$ Fulgentius casts himself in the role of a pupil instructed by Virgil himself, who appears before him as a frowning, notebook-carrying, preoccupied schoolmaster. Virgil begins by explaining, "In all my writings I have introduced themes of natural order, whereby in the twelve books of the Aeneid I have shown the full range of human life" (p. 122) (pp. 86-87: "In omnibus nostris opusculis fisici ordinis argumenta induximus, quo per duodena librorum uolumina pleniorem humanae uitae monstrassem statum"). In the dialogue that follows, Virgil interprets his own epic allegorically, using etymologies to discover a coherent (albeit digressive) account of "the complete state of man" (p. 124)-his natural development from infancy to old age, his gradual acquisition of wisdom through practical experience and disciplined study, his acceptance of toil, his moral struggle against evil and passion, and his heroic encounter (in the image of Juturna's chariot) with Fortune's ever-turning wheel. ${ }^{19}$

In the twelfth century Bernard Silvestris and John of Salisbury,

17. Murrin, Allegorical Epic, p. 23.

18. Fulgentius, "The Exposition of the Content of Virgil according to Moral Philosophy," in Fulgentius the Mythographer, trans. Leslie George Whitbread (Columbus: Ohio State University Press, 1971), p. 119. I quote the Latin text from Opera, ed. Rudolph Helm (Stuttgart: G. B. Teubner, 1970).

19. Jon Whitman astutely observes that "about the time that Fulgentius was closing his interpretive allegory with the concept of Fortune's wheel, Boethius was turning that wheel into the starting point for his own compositional design" (Allegory: The Dynamics of an Ancient and Medieval Technique [Oxford: Clarendon Press, 1987], p. 1122$)$. 
following Fulgentius, unfolded more sophisticated allegorical readings of Virgil, employing a similar anthropocentric scheme. To read the Aeneid in this way, Bernard says, is to take seriously the Delphic oracle's exhortation to self-knowledge. It is, moreover, a very useful thing for a person to know himself: "homini enim magna est utilias ... se ipsum cognoscere." 20 The commentators thus discovered in Virgil a moral philosopher; in Aeneas, a type of the soul imprisoned in the body. ${ }^{21}$ In his actions they perceived sub integumento "all that the human soul does or suffers during its temporary abode in the body" ("quid agat vel quid patiatur humanus spiritus in humano corpore temporaliter positus"). ${ }^{22}$ Thus Aeneas' literal warfare and wanderings, parallel to those of Odysseus, came to be read as his had been: as the homeward journey of the soul to the Fatherland.

\section{The Romancers and the Allegory of Eros}

Whereas the allegory of logos aims at the intellectual discovery of truth, at naming the cosmological and microcosmic causes of things, the allegory of eros aims at the personal application of truth; at feeling, willing, and doing, rather than knowing. Romance, as the "other speaking" of epic, thus aligns itself especially with the otherness of moral allegory, the reading which defines epic action as exemplary. Sir Philip Sidney bears witness to this connection when he names Heliodorus as an epic poet comparable to Homer and Virgil on the grounds that "it is not rhyming and versing that maketh a poet," but moral exemplification, the "feigning notable images of virtues" as "delightful teaching." 23

Unlike Virgil, who subordinated the Odyssey to the Iliad in his refiguration of Homer, the authors of the ancient romances-among

20. Bernard Silvestris, The Commentary on the First Six Books of the "Aeneid" of Virgil Commonly Attributed to Bernard Silvestris, ed. Julian Ward Jones and Elizabeth Frances Jones (Lincoln: University of Nebraska Press, 1 977), p. 3.

21. John of Salisbury, following Fulgentius, describes the Aeneid as a book in which Virgil explores the secrets of all philosophy: "libro in quo totius philosophiae rimatur arcana" (Polycraticus ii, PL 199, c430).

22. Bernard Silvestris, The Commentary, p. 3.

23. Sir Philip Sidney, An Apology for Poetry; or, The Defence of Poesie, ed. Geoffrey Shepherd (London: Thomas Nelson, 1965), p. 103. 
them, Chariton, Xenophon of Ephesus, Heliodorus, Achilles Tatius, and Apuleius - gave prominence to the Odyssey, thematizing its epic truth (as a Platonizing Stoicism had defined it) in popular forms accessible to general audiences. The Stoic moralists, as we have seen, discovered in Odysseus the figure of the virtuous man, bravely bearing the assaults of Fortune, whereas the Neoplatonists saw in him the image of the perfected soul, empowered by heavenly love to detach itself from earthly goods. These two interpretations, as we shall see, conjoin in the romances where literary imitation is selfconsciously rhetorical and aimed at the imaginative participation of its audience.

Reading Homer's Odysseus as a moral exemplar (a reading that was common pedagogical practice) encouraged the audience's identification with him; that identification, in turn, promoted a rewriting of Homer in which his larger-than-life heroes became ordinary people, middle-class heroes and heroines. The moralization of Homer thus established a parallel between the Homeric stories and their retelling in analogous tales that invited similar personal application by the reader. To use Ben E. Perry's phrase, the romance as "latterday epic for Everyman" translated the exemplariness of Homer's heroes and the moral message of their struggles into forms readily accessible to, and imitable by, general audiences. ${ }^{24}$ Thus it became, as Tomas Hägg says, "the epic of the Hellenistic period, fulfilling the functions of epic in a new age." 25 In this sense Perry's words hold true: "Romance and epic are basically the same genre." 26 Radically different in form, they convey the same epic truth.

Although the romances are seldom treated in discussions of an-

24. Ben Edwin Perry, The Ancient Romances: A Literary-Historical Account of Their Origins, Sather Classical Lectures $195^{1}$ (Berkeley: University of California Press, 1967), p. 48. According to Perry, the audience of the romances was a "morally and realistically minded, middle class citizenry" (p. 63).

25. Tomas Hägg, The Novel in Antiquity (Berkeley: University of California Press, $1983)$, p. 111.

26. Ancient Romances, p. 45. Perry attributes the formal differences between epic and romance to the social conditions surrounding their production, epic arising in "closed," centripetal societies; the novelistic romance in "open," centrifugal ones. His treatment of epic and romance in many ways parallels that of M. Bakhtin, The Dialogic Imagination, ed. Michael Holquist, trans. Caryl Emerson and Michael Holquist, University of Texas Press Slavic Series, No. 1 (Austin: University of Texas Press, $1981)$. 
cient epic, they themselves lay an explicit internal claim to a continuous epic-that is, Homeric-tradition through multiple verbal echoes, allusions, and plot parallels. As Robert Lamberton has suggested, the author's intent in each case is imitation. ${ }^{27}$ Chariton's Chaereas and Callirhoe (first or second century A.D.), for example, begins with a wedding "like the wedding of Thetis on Pelion as poets describe it" (p. 24) — the strife-troubled marriage feast that sets the

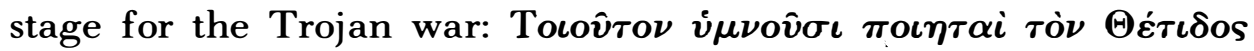
$\gamma \dot{\alpha} \mu о \nu \dot{\varepsilon} \nu \Pi \eta \lambda i \varphi \gamma \varepsilon \gamma o \nu \varepsilon \dot{\nu} \alpha \iota$ (I.I, p. 416). ${ }^{28}$ This Iliadic opening is matched by an Odyssean conclusion when husband and wife, faithful to one another through a long separation and multiple trials, are reunited, a euphoric moment Chariton narrates using Homer's words (Od. 23.296): "they fell into each other's arms and 'gladly turned to the pact of their bed as of old" " (p. 11 2) (VIII.I, p. 493: $\pi \varepsilon \rho \iota \pi \lambda \alpha \kappa \varepsilon \dot{\nu} \tau \varepsilon s$

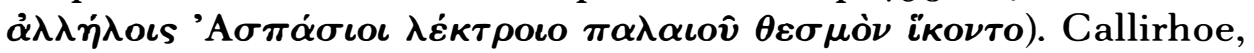
the heroine, worships Aphrodite, whose beauty she embodies. That Helen-like beauty causes her the misfortune to be the wife of two husbands (Chaereas and Dionysius), to awaken desire in a series of would-be lovers, and to occasion discord. At the same time, her chastity and her dilemma in the face of ardent suitors liken her to Penelope-a parallel Chariton underscores by weaving quotations from the Odyssey into his prose narrative. Callirhoe's husband Chaereas similarly combines in his person the qualities of several Homeric figures. He grieves like Achilles at the death of Patroclus (Il. 18.2224) over his separation from Callirhoe: "with both hands he took dark dust and poured it over his head, defiling his lovely counte-

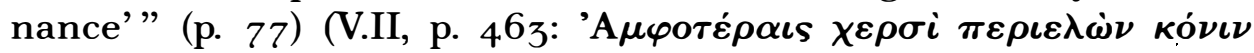

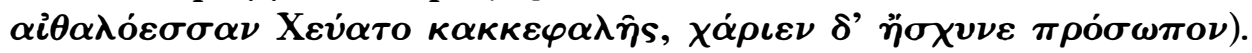
He goes into battle with Hector's words (Il. 22.304-05) on his lips

27. Robert Lamberton, Homer the Theologian: Neoplatonist Allegorical Reading and the Growth of the Epic Tradition (Berkeley: University of California Press, 1986), p. 286.

28. The English translations of the cited romances-Chariton's Chaereas and Callirhoe by B. P. Reardon, Xenophon of Ephesus' An Ephesian Tale by Graham Anderson, Achilles Tatius' Leucippe and Clitophon by John J. Winkler, Heliodorus' An Ethiopian Story by J. R. Morgan-are all taken from Collected Ancient Greek Novels, ed. B. P. Reardon (Berkeley: University of California Press, 1989). The Greek texts of Heliodorus and Chariton are taken from Erotici Scriptores Graeci, ed. G. A. Hirschig (Paris: Didot, 1875). Page references are parenthetical. 
(p. 102) and proves himself as brave as Diomedes (Il. 9.48-49) in a contest resembling that at Troy (Il. 1 3.131, 16.215): "Shield pressed against shield, helmet against helmet, man against man" (p. 105)

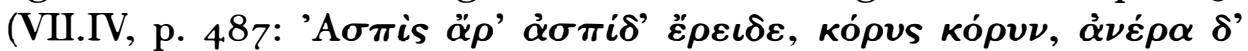
$\dot{\alpha} \nu \dot{\eta} \rho)$. Throughout the romance, direct quotation assimilates the domestic trials of the young couple, their friends, and their parents to the suffering undergone by Homer's legendary heroes. Public interest, we are told, focuses on the case of Callirhoe when it is brought to trial, even as the gods " "sitting at Zeus's side" " (p. 8o) held debate

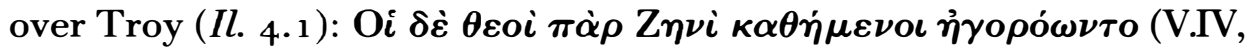
p. 466).

Heliodorus' Ethiopica (third or fourth century A.D.), like Chariton's early romance, combines an Iliadic opening with a conclusion that celebrates an Odyssean homecoming. When the heroine Charikleia makes her first appearance in the garb of a Delphic priestess, her Artemisian description (p. 354) recalls that of Apollo, descending with his deadly arrows from Olympos at the start of the Iliad (1.4647). Charikleia's chaste young lover, Theagenes, is a swift-footed descendant of Achilles, whose handsome appearance attests his ancestry (p. 407). Theagenes' character, however, lacks Achilles' “arro-

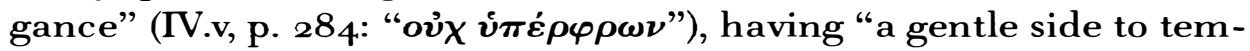
per his pride" (p. 428). Charikleia in her lovesickness first identifies Theagenes as the one she loves by repeating aloud the verse of Homer (Il. 16.21): "Son of Peleus, far greatest of the Achaians,

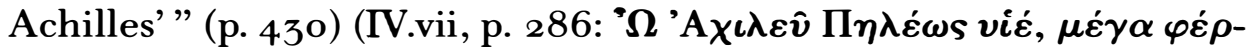
$\tau \alpha \tau^{\prime}$ 'A $\chi \alpha(\hat{\omega} \nu)$. Once wounded in a boar hunt, Theagenes has a scar on his knee like that of Odysseus, which serves him also as a token of recognition (p. 449). In a vision one night Odysseus himself appears to the travelers and extends to Charikleia on her dangerous sea voyage Penelope's special blessing "since she esteems chastity above

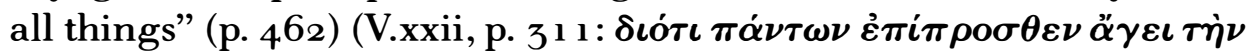
$\sigma \omega \varphi \rho o \sigma v \nu \eta \nu)$. Those who try to force Charikleia into marriage find

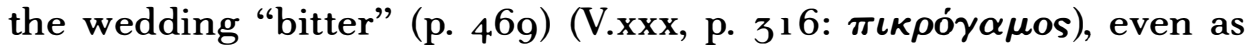
Penelope's suitors did (Od. 1.266, 4.346, 17.137). As beautiful and faithful as Penelope, Charikleia experiences in the end the reward of her tested virtue in a dramatic scene of recognition and reunion.

The character Kalasiris, however, provides the strongest indication that the Ethiopica represents Heliodorus' conscious attempt to 
write a kind of Homeric epic. ${ }^{29}$ Kalasiris, the wise old man who serves as mentor to the young lovers and whose voice narrates a considerable portion of the romance, begins his tale (p. 394) with the same words Odysseus uses (Od. 9.39) to recount his: 'I $\boldsymbol{\lambda} \iota \boldsymbol{\theta}_{\boldsymbol{\theta}} \boldsymbol{\varepsilon} \boldsymbol{\nu} \boldsymbol{\mu} \varepsilon$ $\varphi \varepsilon ́ \rho \varepsilon \iota s$ (II.xxi, p. 258). An Egyptian priest, Kalasiris figures as a type of Homer himself who, we are told, was an "Egyptian poet" (p. 407)

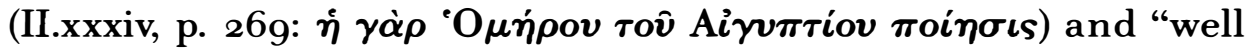

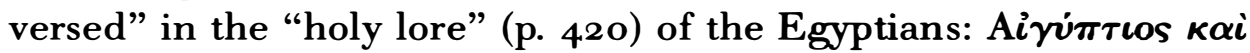

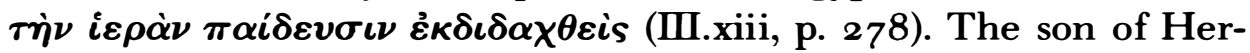

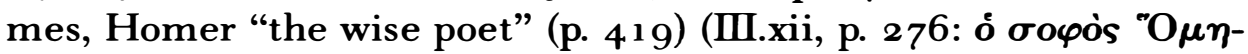
oos) grew up in the precincts of an Egyptian temple where he, trained in the exegetical method usually associated with Alexandria, mastered in his poetry "the typically Egyptian combination of concealed meanings and sheer enjoyment" (p. 421) (III.xv, p. 278 : $\tau$ ò $\alpha \dot{\nu} \varepsilon \iota \mu \varepsilon \dot{\nu} \nu$

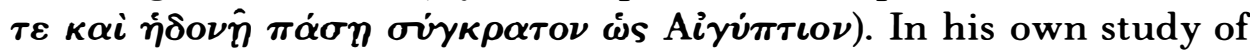
Homer's works, Kalasiris understood at first "the superficial import

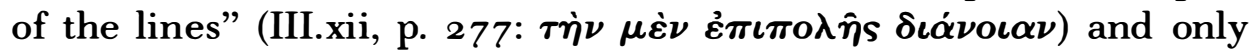
afterward became aware of the "religious teaching embedded in

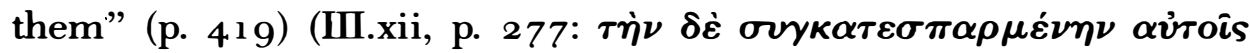

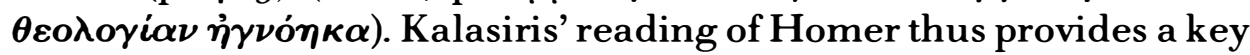
for understanding his own retrospective narrative, and Heliodorus' romance as a whole, as a latter-day epic, different from the Homeric poems in its external form but conveying the same "true wisdom" (p. 421 ) (III.xvi, p. 279: $\dot{\alpha} \lambda \eta \theta \hat{\theta} s \sigma o \varphi i \alpha)$.

The epic truth of the romances is twofold, reflecting in a popular way both the Stoic teachings of necessary subjection to, and possibly victory over, Fortune and the Neoplatonist doctrines of eros and immortality. As we have seen, Seneca responds to the Pythian oracle "Know thyself" by pointing with Stoic realism to the naked weakness and fragility of human beings who are, by nature, "dependent upon another's help, and exposed to all the affronts of Fortune." 30

This mortalist view strikingly informs the romances where the blows of Fortune serve to expose the helplessness and vulnerability of

29. Cf. Lamberton's discussion of Heliodorus in Homer the Theologian, pp. 14957 .

30. Seneca, "Ad Marciam de consolatione," in Moral Essays, vol. 2, trans. John W. Basore, Loeb Classical Library (Cambridge: Harvard University Press, 1932, rev. ed. 1958), XI.3, p. 35. 
the protagonists, all of whom endure serial sufferings. The unfolding plotline of Chariton's Chaereas and Callirhoe is punctuated with the

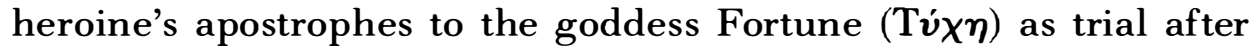
trial besets the young lovers. Xenophon's Ephesian Tale, strongly influenced by Chariton's romance, recounts the adventures of another young married couple, Anthia and Habrocomes, who are separated from one another and finally reunited after a similar series of imprisonments, tortures, travels, and temptations. Like Chariton, Xenophon intersperses pauses in the course of the fast-paced narrative for lamentation, each lament providing an occasion for the preceding misfortunes to be rehearsed. When Heliodorus' heroine, Charikleia, breaks down in a similar fashion under the weight of misfortune, her mentor Kalasiris rebukes her for her "extravagant and unseemly anguish," her "senseless submission to adversity" (p. 481) and exhorts her: "Kindly remember that you are a human being, a creature of change, subject to rapid fluctuations of fortune

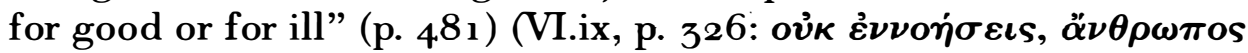

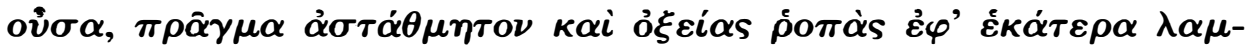
$6 \dot{\alpha} \nu o \nu)$. Taken together, the romances all enforce upon their readers that remembering of human frailty which is, in Seneca's view, essential to self-knowledge and wisdom.

In the romances, however, the recollection of mortality is coupled with the assurance of divine assistance. ${ }^{31}$ Constantly in motion, Fortune serves unchanging destiny, the larger, providential plan which is divinely set (fatum) and which gains expression in the romances in oracles and prophetic dreams. As Chariton observes, "without [Fortune] nothing ever comes to completion" (p. 54) (III.iii, p. 443:

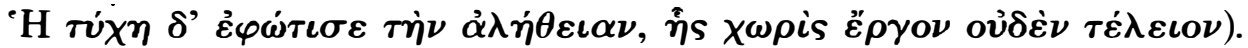
When Anthia and Habrocomes and Charikleia and Theagenes set off on their journeys in response to oracles, they enact the part the Stoics assign to the good man who, in Seneca's words, "offer[s] himself to Fate," consoled by the knowledge that we are all swept along (rapi) with the universe along the same unchangeable course (cursus) and by the same necessity that binds the gods: "eadem

31. As Cicero's Stoic Balbus insists, in opposition to the Epicureans, the care of the gods extends to individuals (De natura deorum II.lxv.164), and oracles, prophecies, dreams, and portents offer the strongest proof of that providential concern (II.lxv. $162-$ $63)$. 
necessitate et deos alligat." 32 We are all, as Heliodorus' theatrical metaphors emphasize, players in the often spectacular drama of destiny.

Educated and purified by the blows of Fortune, strengthened in virtue, the lovers of the romances gradually achieve a steadfastness that likens them to the fixity of Fate itself. ${ }^{33}$ Godlike in the faithfulness of their love, raised above the material sphere where Fortune exerts her influence, the long-suffering couples merit the assistance they receive on their homeward journey. Against terrible odds, Habrocomes and Anthia fulfill their oaths of mutual fidelity and find each other at last in the temple of Helius, the sun god. Callirhoe's loyalty to Chaereas assimilates her to the heavenly Aphrodite, whom she worships, and who presides over the lovers' first meeting and their reunion. Theagenes and Charikleia maintain mutual fidelity and virginal chastity, virtues that ultimately secure their marriage and their consecration as priest and priestess of the Sun and Moon.

The overt religiosity of the romances, coupled with the dominant theme of faithful love and the plot of a homeward journey ("ad patriam"), easily assimilates them to the Platonic scheme of a spiritual ascent inspired by eros. Achilles Tatius' Leucippe and Clitophon "abounds," as John J. Winkler observes, in "covert references" to Plato's Phaedrus and Symposium, where Socrates uses Homer to discover the doctrine of love. ${ }^{34}$ Heliodorus' Ethiopica interprets the opening description of Charikleia gazing at the wounded Theagenes in words reminiscent of Phaedrus 252a: "Genuine affection and wholehearted love disregard all external pains and pleasures and compel the mind to concentrate thought and vision on one object: the beloved" (p. 355) (I.II, p. 227 : Ov้

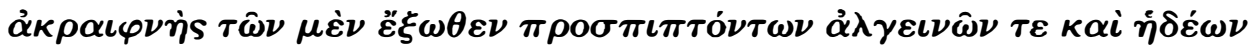

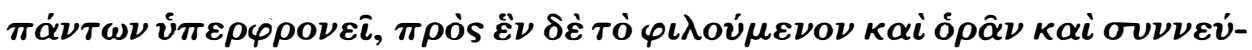
$\varepsilon \iota \nu \tau \dot{o} \varphi \rho o ́ \nu \eta \mu \alpha \kappa \alpha \tau \alpha \nu \alpha \gamma \kappa \dot{\alpha} \zeta \varepsilon \iota$.). A romance that frequently "hints at mystical allegory," 35 the Ethiopica clearly encouraged its early read-

32. Seneca, "De providentia," in Moral Essays, vol. 1, trans. John W. Basore, Loeb Classical Library (Cambridge: Harvard University Press, 1958), V.8, pp. 38-39.

33. Seneca emphasizes the divine pedagogy that allows good people to struggle with misfortune in "De providentia," IV.11-16, pp. 30-35.

34. John J. Winkler, Leucippe and Clitophon, in Collected Ancient Greek Novels, n. 6, p. 177. For an ironic treatment of the Platonic echoes, see Graham Anderson, Eros Sophistes: Ancient Novelists at Play (Chico, Calif.: Scholars Press, 1982).

35. Lamberton, Homer the Theologian, p. 157. 
ers to discover one. Philip the Philosopher's fragmentary exposition of the Ethiopica (late fifth century?) elaborates on Heliodorus' own Platonizing narrative with an allegorical reading that is, as Lamberton has shown, "quite close" to the Neoplatonic allegories of Homer. ${ }^{36}$ According to Philip, the lovers are not only models of the "four general virtues"; Charikleia is also the symbol of the soul and of the mind. ${ }^{37}$ In her whole-hearted love for Theagenes, she resembles the soul that "transcends the material dyad" and contemplates her "true family." Filled with "the love of highest wisdom," she "scorns her former habits, utterly unmindful of her body, and her thought tends only toward her beloved." Advancing "toward her own country," the soul endures "trial by fire," until, "radiant," she returns to the place of her origin. ${ }^{38}$

The two Odyssean allegories-Stoic and Neoplatonic-we have found refigured in the romances clearly define the outer and inner structure of Apuleius' second-century Latin romance, the Metamorphoses. Apuleius' satiric frame tale extends Stoic moral commentary on Homer's Calypso and Circe episodes ( $O d .5$ and 1o) into the story of Lucius, a young man whose ungoverned curiosity and lust indirectly cause his magical transformation into an ass. Lacking in wisdom and self-control, Lucius subjects himself to the Fortune over which the wise Ulysses triumphed. The romance begins with a traveler's cautionary exemplum, the story of Socrates. Seduced by Meroe, a Circe-like witch who turns her neighbors into beavers, frogs, and rams, Socrates flees from her clutches only to be murdered in an inn by the self-proclaimed "Calypso," who revenges herself cruelly upon this would-be "Ulysses in his craftiness" (p. 39): "At ego scilicet Ulixi astu deserta vice Calypsonis" (Met. I.12). ${ }^{39}$ Lucius, however, fails to apply the lesson to himself and in his curiosity about magic falls victim to the concoctions of Pamphile, a sorceress. Near the end of his serial misfortunes in the form of an ass, Lucius

36. Ibid., p. 148.

37. Ibid., p. 308. Lamberton provides a complete translation of Philip's fragmentary commentary, pp. 306-11.

38. Ibid., pp. 310-11.

39. English translations, cited parenthetically, are from Apuleius, The Golden Ass, trans. Jack Lindsay (Bloomington: Indiana University Press, 1932, 1962). For the Latin text I use Apuleius, Metamorphoses, 2 vols., ed. and trans. J. Arthur Hanson, Loeb Classical Library (Cambridge: Harvard University Press, 1989). 
compares himself ironically to Ulysses. Whereas "the Divine Author of the ancient poetry of the Greeks, desiring to depict a man supremely wise and humanly perfected, sang of him who had visited many cities and known many people" (p. 192) (IX.13: "Nec.immerito priscae poeticae divinus auctor apud Graios summae prudentiae virum monstrare cupiens, multarum civitatium obitu et variorum populorum cognitu summas adeptum virtutes cecinit"), Lucius can only say of himself and his travels: "hidden under the ass's skin, I perceived all life's variety and acquired much knowledge, if little wisdom" (p. 192) (IX.13: "me suo celatum tegmine variisque fortunis exercitatum, etsi minus prudentem, multiscium reddidit").

As a Neoplatonic counterpart and corrective to the Tale of Lucius, the story of Cupid and Psyche occupies the structural center of the Metamorphoses. Like the romances of Chariton and Xenophon of Ephesus, the plot concerns the initial bliss, subsequent trials, and final reunion of a young married couple. The protagonists, however, virtually personify the Platonic doctrine of love and reenact Homer's allegorized Odyssey. Psyche refigures and feminizes Odysseus, read as a type of the soul, whereas Cupid, according to Apuleius' own explanation, represents a daemon or genius of the soul, by virtue of which one is perfected through ardent desire of the Good: "bona cupido animi bonus deus est." 40 This eros moves the soul, even as Athena, personifying divine wisdom, directed Odysseus. ${ }^{41}$ The soul descends when its own desire takes visible form, as when Psyche gazes on Cupid, but the soul in love with Eternal Love (Met. V.23: "magis magisque cupidine flagrans Cupidinis") valiantly endures the suffering of purification until, as James Tatum phrases it, "a bond is established between Soul and god through the agency of Love." 12 The soul thus attains knowledge of the divine, a blissful sapience imaged in the Olympian wedding feast.

A Platonic allegory, the Psyche-romance is also an allegory of Lucius' history. The sacrilegious inquisitiveness of Psyche into her husband's identity, like Lucius' curiosity about magic, leads her to

40. Apuleius, De deo Socratis, in De philosophia libri, ed. Paul Thomas (Stuttgart:

B. G. Teubner, 1970), XV, p. 23.

41. See De deo Socratis XXIV, p. 35.

42. James Tatum, Apuleius and the Golden Ass (Ithaca: Cornell University Press, 1979), p. 61 . 
lose her happy state as Cupid's bride, and her wanderings and labors in search of Cupid distantly parallel those of the unhappy ass in search of a cure. At one point a jealous Juno afflicts Psyche, even as Virgil's Juno torments Aeneas, and thus becomes the analogue of the blind Fortune ("Fortuna caeca") that abuses Lucius while, at the same time, directing him unknowingly to his goal: "istam beatitudinem improvida produxit malitia" (Met. XI. 15). ${ }^{43}$ In the end Psyche is saved, as Lucius is, by a divine intervention, her restoration and deification prefiguring his physical transformation by Isis and his spiritual conversion to her priestly service. As a counterpart to the Heavenly Venus, symbolized by the harmony of the Olympian marriage between Psyche and Cupid, Isis brings order into Lucius' chaotic quest.

Apuleius' artistry, which establishes the Psyche-romance as the inner allegory of Lucius' ironic Odyssey, thus provides an apt contemporary illustration for the reading of ancient romance. As the "other speaking" of epic, romance exemplifies its moral and spiritual meaning. The difficulty, both for an ass-auditor like Lucius and for all of us as unconverted beings, still enslaved by the body and not our true, spiritual selves, is to perceive the analogy and, at the same time, endure the existential difference. Charite, the captive maiden who shares Lucius' lot among the bandits and who, like Psyche, is rescued by the man she loves, experiences no happy ending to her earthly romance. She, like Lucius, draws comfort from the tale of Psyche-a story Apuleius presents as wise foolishness, the (possibly inspired) babbling of a drunken, old woman (Met. VI.25) - only to have her own life story depart dramatically from Psyche's when her beloved husband is murdered, and she herself turns into a cruel avenger and suicide.

The allegorical juxtaposition of romance and realism in Apuleius suggests that the romantic figuration of epic truth needs to be grounded constantly in its own "other speaking," in the recall of tragic possibilities. ${ }^{44}$ The lover, after all, occupies a precarious position in the Platonic scheme. Possessing a fresh memory of Eternal

43. See Tatum, Apuleius, pp. 49-50.

44. Tatum observes that the same "jarring contrasts" that figure in Book VI are characteristic of the "popular philosophy" (p. 64) of the time, as evidenced in the Stoicism of Marcus Aurelius, an emperor contemporary with Apuleius. 
Beauty, he is strongly attracted to its embodiment in visible, corporeal beauty and in the beauty of noble souls. That fervent attraction, based on affinity, enables the lover's spiritual ascent, but only at the cost of painful detachment, of recognizing the vast difference between the eternal and the temporal. As Boethius' Orpheus shows, the lover who fails to rise, falls.

The two lines of allegorical interpretation we have been tracingcosmological and moral, universal and personal-with their respective appeals to logos and eros, converge in the works of both Martianus Capella (fl. A.D. 410-29) and Boethius (A.D. 48o?-526). Martianus' De nuptiis combines, albeit in a discordant and mechanical manner, the late-antique pedantry of the first with the amatory interest of the latter, using the episode of Psyche and Cupid from Apuleius' Metamorphoses as his principal model for his allegorical framestory of courtship and marriage. ${ }^{45}$ Philologia's union with Mercury, like Psyche's with Cupid, is approved by an assembly of gods and goddesses; she ascends to heaven after suitable labors prove her worthy of immortality; and finally she weds her divine husband, with the consent and assistance of Venus, amid general celestial rejoicing.

Before the marriage is finally consummated, however, the assembled wedding guests must listen to the book-long speeches of each of the personified liberal arts. While the song of Harmony at the conclusion of De nuptiis (Book IX) finally unites the erudite discourses of the artes with the plot of courtship and actually seals the marriage between Mercury and Philology, readers are likely to join Martianus' Venus in complaint about the long delay and question the effectiveness of Martianus' solution to what Emerson Brown, Jr., has called the "conflict between the classroom and the bedroom." 16

Boethius' De consolatione, in contrast, combines the themes of

45. See William Harris Stahl and Richard Johnson with E. L. Burge, Martianus Capella and the Seven Liberal Arts, vol. 1, Records of Civilization Series 84 (New York: Columbia University Press, 197 1), pp. 32, 42, 84 .

46. See Martianus Capella, De Nuptiis Philologiae et Mercurii, ed. James Willis (Leipzig: Teubner, 1983), IX.89o, pp. 338-39; Emerson Brown, Jr., "Epicurus and Voluptas in Late Antiquity: The Curious Testimony of Martianus Capella," Traditio 38 (1982): 75-1 06, p. 98. For an interpretation stressing Martianus' attempt to harmonize the universe he imitates, see Fannie J. LeMoine, Martianus Capella: A Literary Reevaluation (Munich: Salzer, 1972). 
knowledge and love, using not the final speech of a personified Harmony, but rather Philosophia's song of the musician, Orpheus (III.m12). ${ }^{47}$ In the myth of Orpheus and Eurydice, central to the Consolation as a whole, Boethius brings seamlessly together the two traditions of eros and logos that Martianus sets side by side. Indeed, as Jon Whitman puts it, Boethius' work begins where that of Martianus and Fulgentius ends and thus "completes the cycle of allegorical transition from late antiquity to the Middle Ages." 18

In its literal terms, the tale of Orpheus and Eurydice realizes the tragic potential of popular romance and inverts the myth of Psyche. In it a virtuous, newly married couple is separated; the partners undertake a long, difficult journey (in this case, to and from the underworld) in the hope of being reunited; their mutual faithfulness wins the favor of the gods; their quest, however, governed by the laws of love and fate, results not in a happy reunion, but in a second, final separation.

The Consolation tells the tale, moreover, in a way that dramatizes the rhetorical impact of romance as a genre. Boethius, listening to Philosophia's song, identifies with Orpheus and, sharing in his sorrow, experiences anew the pain of his own attachment to earthly things (eros). With the force of moral allegory, the Orphic romance reveals to Boethius both what he has been and what he must become if he wishes his own life story to have a happy ending.

When Philosophia echoes Virgil's Georgics 2 and 4 in her rendition of the myth and then invites Boethius to take flight on her pinions, to succeed in the ascent where Orpheus has failed, she joins logos to eros. The cosmological vision and the rational insight into the causes of things that she offers Boethius depend on, and are inseparable from, his affective self-knowledge and directed power of love. The logos of Boethius' universe is amor; his knowing, loving. Philosophia's gown is decorated with emblems of the seven liberal arts, practical and theoretical, but unlike Martianus, who separates them, she decries their partition and insists upon their submission to a single pursuit: the knowledge of one's self. That Boethian pursuit, as we shall see, assumes epic proportions.

47. Martianus' Harmony (IX.907, pp. 345-46) tells the story of Orpheus briefly.

48. Whitman, Allegory, p. 112. 